\title{
Vegetative development of vine rootstock cultivars in brazilian cerrado conditions
}

Luiz Fernandes Cardoso Campos $^{1}$, Eduardo Pradi Vendruscolo ${ }^{2}$, Sávio Rosa Correia ${ }^{1}$, Camila Meira de Abreu Campos $^{1}$ Adriana Teramoto ${ }^{1}$, Mara Fernandes Moura ${ }^{3}$, Alexsander Seleguini ${ }^{4}$

${ }^{1}$ Universidade Federal de Goiás - UFG, GO. ${ }^{2}$ Universidade Estadual de Mato Grosso do Sul - UFMS, MS. ${ }^{3}$ Instituto Agronômico de Campinas - IAC, SP. ${ }^{4}$ Universidade Federal do Triângulo Mineiro - UFTM, MG. E-mail: luizfernandes.agronomo@gmail.com

\begin{abstract}
In the State of Goiás, studies related to the vine's responses to the region's edaphoclimatic conditions are scarce. Therefore, the objective of this work was to evaluate the growth of three vine rootstock cultivars, IAC 572 'Jales', IAC 313 'Tropical' and IAC 766 'Campinas', in the region of Goiânia, GO, after drastic pruning for uniformity. To evaluate the growth of rootstocks, the experiment was carried out in random blocks, in a double factorial scheme (3x7), with five replications, each repetition formed by a plant. The first factor consisted of three rootstocks: IAC 313 'Tropical', IAC 572 'Jales' and IAC 766 'Campinas'. The plants were evaluated after 45 days after a drastic uniformization pruning, totaling seven evaluations $(45,60,75,90$, $105,120,135$ days after pruning), this being the second factor. The diameter of the main branch at the height of grafting $(80 \mathrm{~cm})$ and length of the main branch were evaluated. With the data on the diameter and length of the main branch, the absolute growth rate in diameter and length was calculated. The IAC 572 'Jales' rootstock cultivar has greater vigor for branch growth, being $69 \%$ and $47.3 \%$ longer in length, and $49.8 \%$ and $18.8 \%$ longer in diameter than the IAC rootstock. IAC 313 'Tropical' 'and' IAC 766 'Campinas', respectively. The IAC 766 'Campinas' rootstock cultivar, although it has low vigor in branch growth, presents satisfactory development.
\end{abstract}

Keywords: growth index; tropical viticulture; Vitis spp.

\section{Desenvolvimento vegetativo de cultivares de porta-enxerto de videira em condições de cerrado brasileiro}

\section{Resumo}

No Estado de Goiás são escassos os estudos relacionados às respostas da videira às condições edafoclimáticas da região. Portanto, objetivou-se com este trabalho avaliar o crescimento de três cultivares porta-enxerto de videira, IAC 572 'Jales', IAC 313 'Tropical' e IAC 766 'Campinas', na região de Goiânia, GO, após poda drástica para uniformização. Para avaliar o crescimento dos porta-enxertos, o experimento foi realizado em blocos ao acaso, em esquema fatorial duplo (3x7), com cinco repetições, cada repetição formada por uma planta. O primeiro fator consistiu em três porta-enxertos: IAC 313 'Tropical', IAC 572 'Jales' e IAC 766 'Campinas'. As plantas foram avaliadas a partir de 45 dias após uma poda drástica de uniformização, totalizando sete avaliações $(45,60,75,90,105,120,135$ dias após a poda), sendo este o segundo fator. Foram avaliados o diâmetro do ramo principal à altura de enxertia $(80 \mathrm{~cm})$, e comprimento do ramo principal. De posse dos dados do diâmetro e comprimento do ramo principal, calculou-se a taxa de crescimento absoluto em diâmetro e comprimento. O cultivar porta-enxerto IAC 572 'Jales' apresenta maior vigor para crescimento de ramo, sendo em comprimento $69 \%$ e $47,3 \%$ superior, e em diâmetro 49,8\% e 18,8\% superior aos porta-enxertos IAC 313 'Tropical' e 'IAC 766 'Campinas', respectivamente. A cultivar porta-enxerto IAC 766 'Campinas' embora, tenha vigor baixo em crescimento de ramo, apresenta desenvolvimento satisfatório.

Palavras-chave: taxa de crescimento; viticultura tropical; Vitis spp. 


\section{Introduction}

The propagation of the grapevine (Vitis spp.) in Brazil is mainly based on grafting, with the purpose of obtaining plants with a resistant root system or tolerant to adverse soil conditions, diseases or root pests. In addition, reduce the period of junvenil, obtaining more productive plants and fruits with adequate quality for the markets, as well as replacing canopy cultivars in already installed vineyards (LEÃO; SOARES, 2009). The diversification of rootstocks can be an important strategy in relation to soil heterogeneity and the occurrence of diseases, influenced by the climatic factors of each region, observed in most commercial grape cultivations in Brazilian states (NAVES et al., 2006).

Agronomic and physiological characteristics of canopy cultivars such as vigor, yield, size of clusters and berries, partition of photoassimilates, sugar content and acidity of fruits and other compounds important for quality can be influenced by rootstocks (SILVA et al., 2015; SILVA et al., 2017; TECCHIO et al., 2019). However, the choice of the rootstock in viticulture depends on the soil conditions of each producing region and, within a region, it can still undergo many variations, which makes this a difficult choice, therefore research works must be repeated for each cultivation site (LEÃO et al., 2011).

The Agronomic Institute of Campinas (IAC) was a pioneer in the development of several cultivars of tropical rootstocks, among which IAC 313 'Tropical', IAC 571-6 'Jundiaí', IAC 572 'Jales' and IAC 766 'Campinas', present in the table grape-producing regions, for their exceptional qualities of vigor and adaptability (POMMER, 2001). The IAC 313 'Tropical' rootstock originated from the cross between Golia and Vitis cinerea. Vigorous, it adapts well to different types of soil and its leaves have good resistance to fungal diseases (mildew and anthracnose) and to Meloidogyne nematodes. IAC 572 'Jales' was obtained from the cross between Vitis caribaea and 101-14 Mgt (Vitis riparia and Vitis rupestres). It is also vigorous, vegetates well in both clayey and sandy soils, with disease resistant leaves. The IAC 766 'Campinas' originated from the intersection between Ripária do Traviú and Vitis caribaea. Its leaves are quite resistant to diseases caused by fungi and its branches hibernate better than the rootstocks IAC 313 'Tropical' and IAC 572 'Jales' (TERRA et al., 2001; SOUZA; MARTINS, 2002).

In the State of Goiás, studies focused on the analysis of the phenological and productive behavior of the grapevine are scarce, mainly in relation to the development of rootstocks. The need to know the responses of the grapevine to the edaphoclimatic conditions of the region, in relation to the use of an appropriate rootstock, will allow adjustments to be made in the management and production system of the grapes (SOUZA et al., 2012; CAMPOS et al., 2017). Therefore, the objective of this work was to evaluate the growth of three vine rootstock cultivars, IAC 572 'Jales', IAC 313 'Tropical' and IAC 766 'Campinas', in the region of Goiânia, GO, after drastic pruning for uniformity.

\section{Material and Methods}

The experiment was carried out in the experimental area of the Agronomy School, Federal University of Goiás $\left(16^{\circ} 35^{\prime} \mathrm{S}, 49^{\circ} 16^{\prime} \mathrm{O}\right.$ and altitude of $725 \mathrm{~m}$ ), Goiânia, Goiás. The climate, according to the Köppen-Geiger classification, is Aw type (tropical with dry season in winter) (ALVARES et al., 2013; CARDOSO et al., 2014). The soil was classified as a Latossolo Vermelho distrófico (SANTOS et al., 2013). The climatic records during the conduct of the experiment were obtained from a climatic station located $270 \mathrm{~m}$ from the test site (Figure 1).

Before planting, chemical and physical analysis of the soil was carried out in the $0-0.20$ $\mathrm{m}$ deep layer, which had the following characteristics: $\mathrm{pH}$ in $\mathrm{CaCl}_{2}=4,9$; organic matter $=$ $1,2 \mathrm{~g} \mathrm{~kg}^{-1} ; \mathrm{P}$ Mehlich $=5 \mathrm{mg} \mathrm{dm}^{-3} ; \mathrm{Al}=0,0 \mathrm{cmol}_{\mathrm{c}}$ $\mathrm{dm}^{-3} ; \mathrm{H}+\mathrm{Al}=2,7 \mathrm{cmol}_{\mathrm{c}} \mathrm{dm}^{-3} ; \mathrm{K}=0,24 \mathrm{cmol}_{\mathrm{c}} \mathrm{dm}^{-3} ;$ $\mathrm{Ca}=2,1 \mathrm{cmol}_{\mathrm{c}} \mathrm{dm}^{-3} ; \mathrm{Mg}=0,6 \mathrm{cmol}_{\mathrm{c}} \mathrm{dm}^{-3} ; \mathrm{CTC}=$ $5,6 \mathrm{cmol}_{\mathrm{c}} \mathrm{dm}^{-3} ; \mathrm{V}=52 \%$; clay $=310 \mathrm{~g} \mathrm{~kg}^{-1}$; silt $=$ $180 \mathrm{~g} \mathrm{~kg}^{-1}$ e sand $=51 \mathrm{~g} \mathrm{~kg}^{-1}$. Liming was carried out, sixty days before planting, using $823 \mathrm{~kg} \mathrm{ha}^{-1}$ of dolomitic limestone and corrective fertilization of phosphorus at a dose of $100 \mathrm{~kg} \mathrm{ha}^{-1}$, using simple superphosphate, both in total area, as recommended by Sousa and Lobato (2004). 
Figura 1. Rainfall, maximum, minimum and average temperature, during the period of the experiment. ${ }^{1}$ growth period of rootstocks, after planting the seedlings; ${ }^{2}$ evaluation period of rootstock growth after uniform pruning.

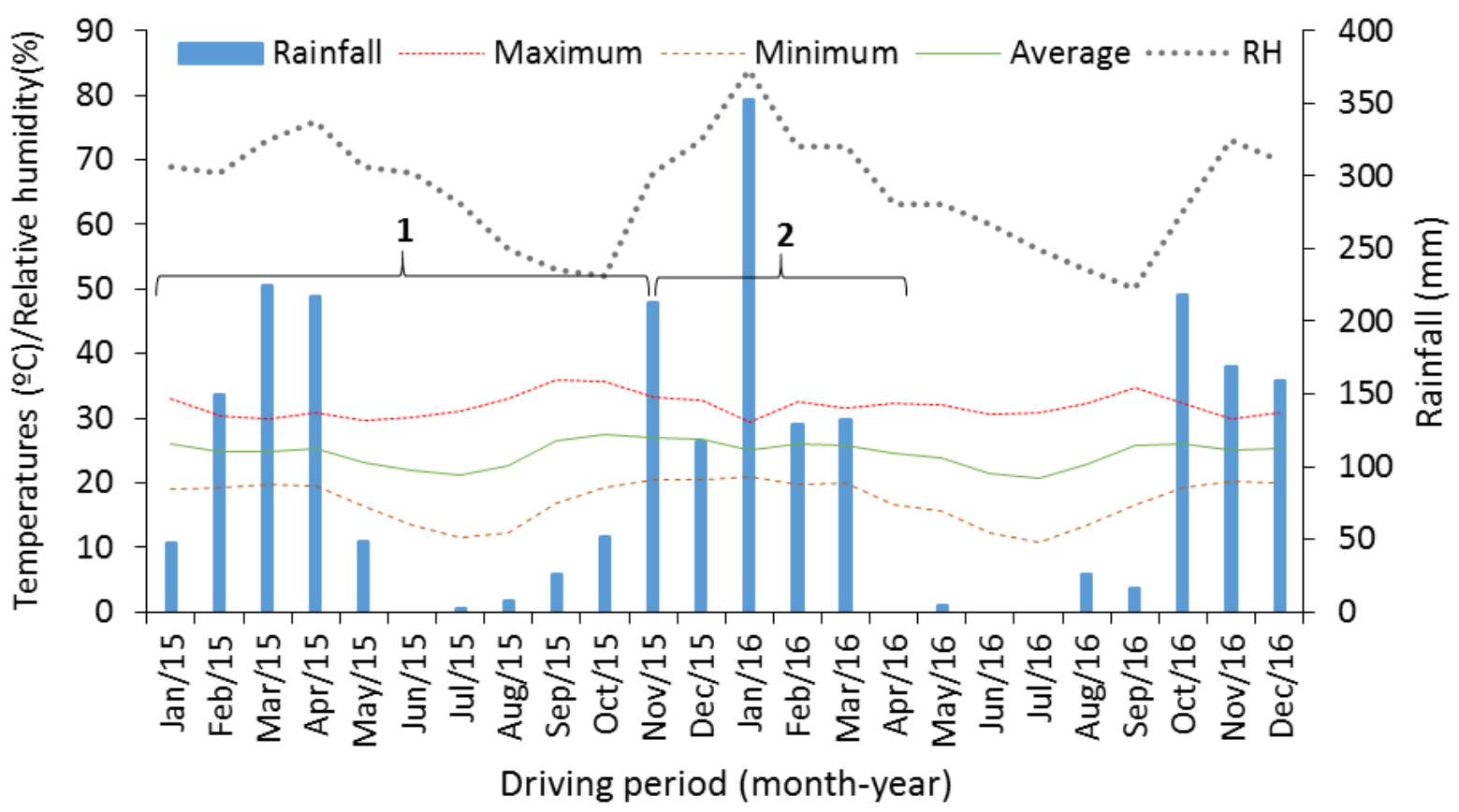

The vineyard was implanted in a $2.0 \times 2.5$ $\mathrm{m}$ spacing between plants and between lines, respectively, in the trellis type conduction system, with a micro sprinkler irrigation system, using emitters with a flow rate of $55 \mathrm{~L} \mathrm{~h}^{-1}$, spaced in $2.5 \mathrm{~m}$, with $100 \%$ wet area. The cuttings used as propagating material for the formation of the rootstocks were provided by the Banco Ativo de Germoplasma, from the Advanced Fruit Research Center of the Agronomic Institute of Campinas (IAC), in Jundiaí, in the State of São Paulo. The cuttings, with three to four buds, were placed to take root in plastic bags, with a capacity of $2 \mathrm{~L}$, filled with substrate based on subsoil layer, corrected and fertilized with lime and simple superphosphate. (SOUSA; LOBATO, 2004).

The seedlings formed were transplanted to the experimental area on January 15, 2015. In order to homogenize the height of the plants, a drastic pruning was performed on December 2, 2015, $50 \mathrm{~cm}$ from the soil. After sprouting, two more vigorous shoots were selected to be conducted, up to the wire of the conduction system.

To evaluate the rootstocks growth, the experiment was carried out in random blocks, in a double factorial scheme $(3 \times 7)$, with five replications, each plot formed by five plants. The first factor consisted of three rootstocks: IAC 313 'Tropical', IAC 572 'Jales' and IAC 766 'Campinas'. The plants were evaluated from 45 days after drastic pruning, totaling seven evaluations (45, $60,75,90,105,120,135$ days after pruning), being the second factor.

To monitor the growth of the rootstocks, the diameter of the main branch at the height of grafting $(80 \mathrm{~cm})$ was evaluated, with the aid of a digital caliper and the length of the main branch, measured with the aid of a measuring tape. With data on the diameter and length of the main branch, non-destructive analysis, the absolute growth rate (AGR) in diameter $\left(\mathrm{mm} \mathrm{day}^{-1}\right)$ and in length $\left(\mathrm{cm}\right.$ day $\left.^{-1}\right)$ was calculated using Equation 1, described by Silva et al. (2000):

$$
A G R=(L 2-L 1) \div(t 2-t 1)
$$

Where: $L 1$ is the length or diameter of the branch at time t1 and L2 is the length or diameter of the branch at time $t 2$.

The data were submitted to analysis of variance, being compared by the Tukey test when referring to the qualitative factor (rootstock) and to the regression analysis for the quantitative factor (days after pruning), with a probability of $5 \%$. Data on growth rates were compared using the Tukey test. For the analyzes, the SISVAR 5.6 software was used (FERREIRA, 2019). 


\section{Results and Discussion}

There was an interaction between the two factors studied (rootstock $x$ days after pruning) for the length and diameter of branches (Figure 2 and Figure 3). Regarding the length of branches, a positive linear regression adjustment was found for the three rootstocks evaluated (Figure 2).

Figure 2. Interaction for main branch length $(\mathrm{cm})$ in three vine rootstock cultivars (IAC 313 'Tropical', IAC 572 'Jales' and IAC 766 'Campinas') as a function of the days after uniform pruning.

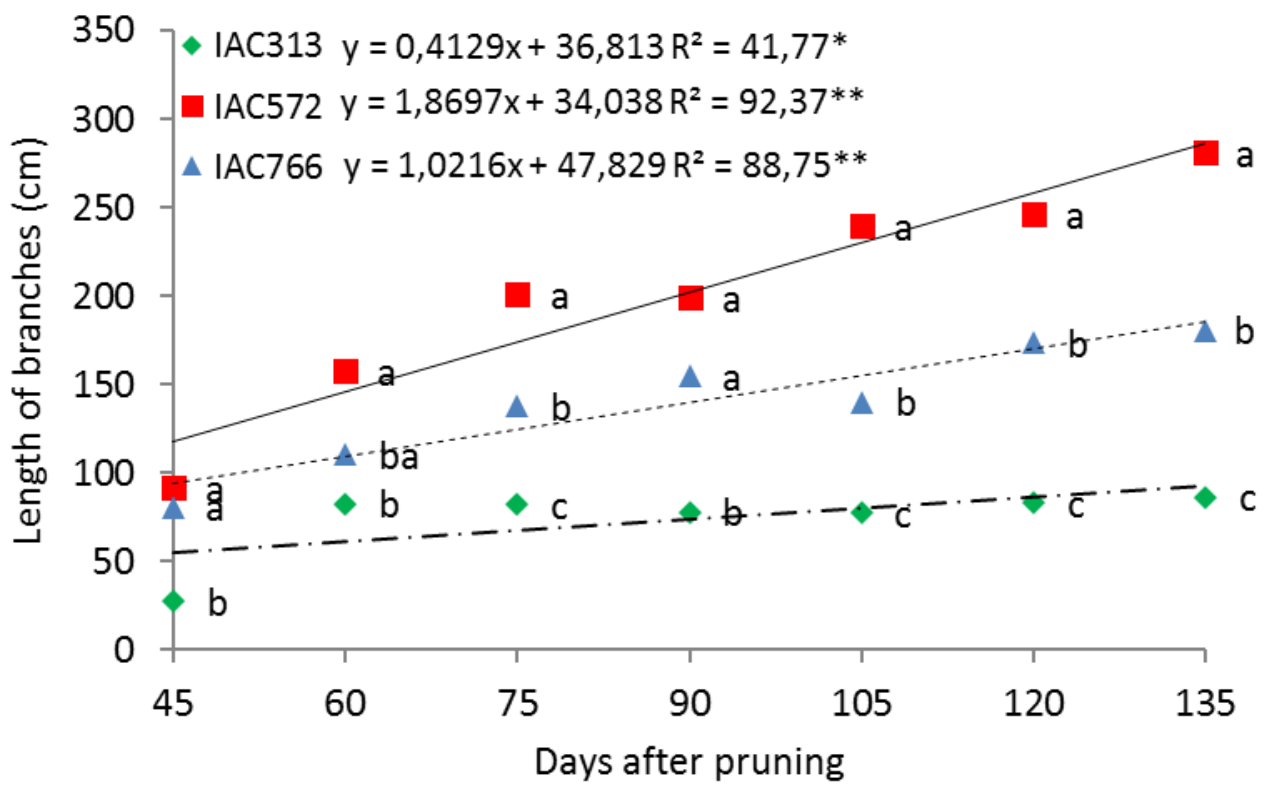

${ }^{* *}$ significant $(p<0,01) .{ }^{*}$ significant $(p<0,05)$. Different letters, between rootstocks, indicate significance by the Tukey test, at $5 \%$ probability.

The IAC 572 'Jales' rootstock showed a higher growth than the others, mainly after 75 days after pruning (Figure 2). The best performance observed for this rootstock may be related to wide adaptation to different types of soil, resistance to leaf diseases and high vigor. The increments in length of the main branch were 190, 100 and $59 \mathrm{~cm}$ for IAC 572 'Jales', IAC 766 'Campinas' and IAC 313 'Tropical' respectively, throughout the assessment period. Similar results were reported by Silva et al. (2010) evaluating different rootstocks in the West of the State of Paraná, a region typically of subtropical climate, regarding the vegetative performance of the rootstock IAC 572 'Jales', a greater length of the largest branch was noted. However, the authors report greater growth of IAC 313 'Tropical' and lower growth for IAC 766
'Campinas', but without significant difference between them. Result different from this work, for IAC 313, where lower branch length values were observed (Figure 2).

For the cultivar IAC 572 'Jales', positive linear behavior was identified for the diameter at the time of grafting (Figure 3), indicating constant and regular growth depending on the evaluation period. For IAC 766 'Campinas' and IAC 313 'Tropical' there was no regression adjustment. The greatest increases in diameter were found for IAC 572 'Jales' and IAC 766 'Campinas', with a significant difference between the two rootstocks only at 105 and 135 days after pruning. 
Figure 3. Interaction for main branch diameter $(\mathrm{mm})$, at $80 \mathrm{~cm}$ in height, in three vine rootstock cultivars (IAC 313 'Tropical', IAC 572 'Jales' and IAC 766 'Campinas') as a function of days after uniform pruning.

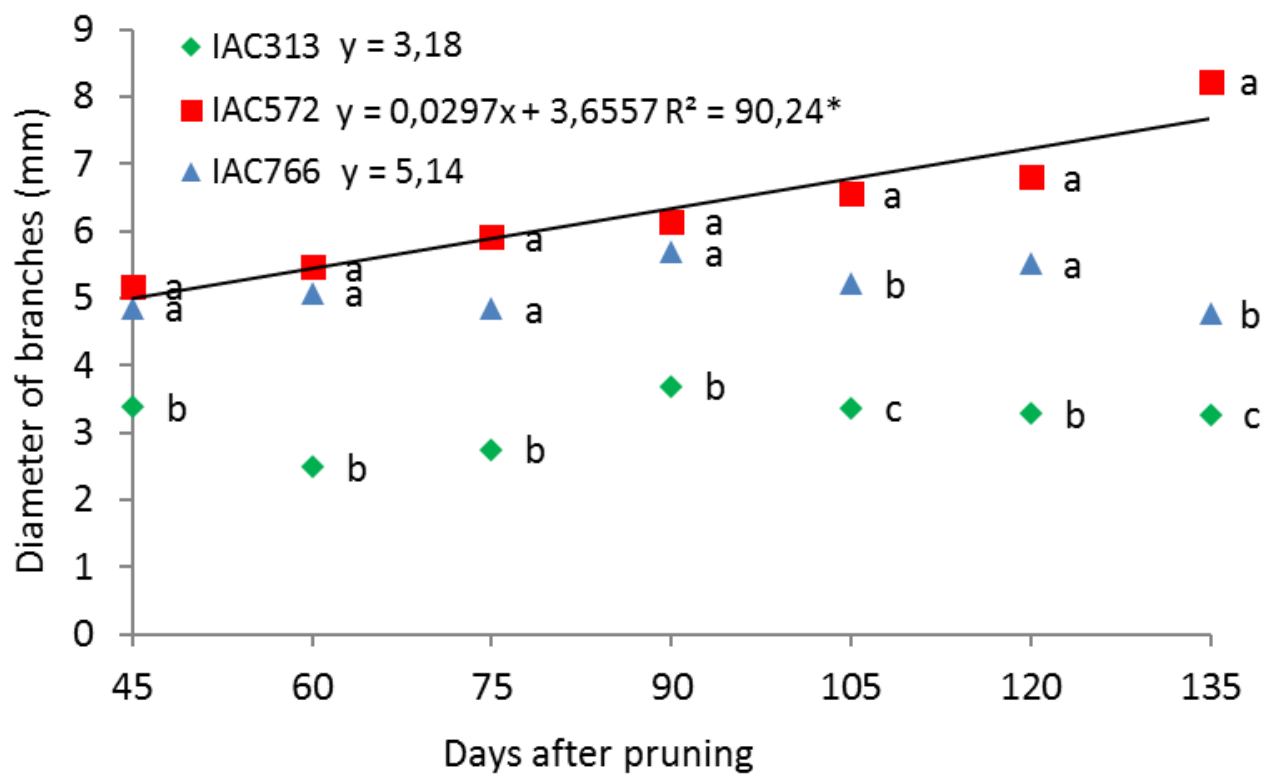

** significant $(p<0,01) .{ }^{*}$ significant $(p<0,05)$. Different letters, between rootstocks, indicate significance by the Tukey test, at $5 \%$ probability.

The IAC 313 'Tropical' presented lower averages than the other rootstocks during the entire evaluation period (Figure 3), mainly due to the low development, induced by the defoliation of the young seedling, caused by the incidence of downy mildew (Plasmopara vitícola) in this rootstock while conducting the experiment (Figure 4). No reports of susceptibility were found in the literature, however, for the environmental conditions observed in this study, the average temperature around $25.6^{\circ} \mathrm{C}$ and the average relative humidity around $73 \%$ (Figure 1 ) favored the development of the disease. In addition, preventive treatments using fungicides have not been carried out. According to Almança et al. (2015) the optimal temperatures for the occurrence of downy mildew vary from 18 으 to $25 \circ \mathrm{C}$ and relative humidity above $70 \%$.

Figure 4. Symptoms of mildew incidence (Plasmopara vitícola), on the IAC 313 'Tropical' rootstock, GoiâniaGO.
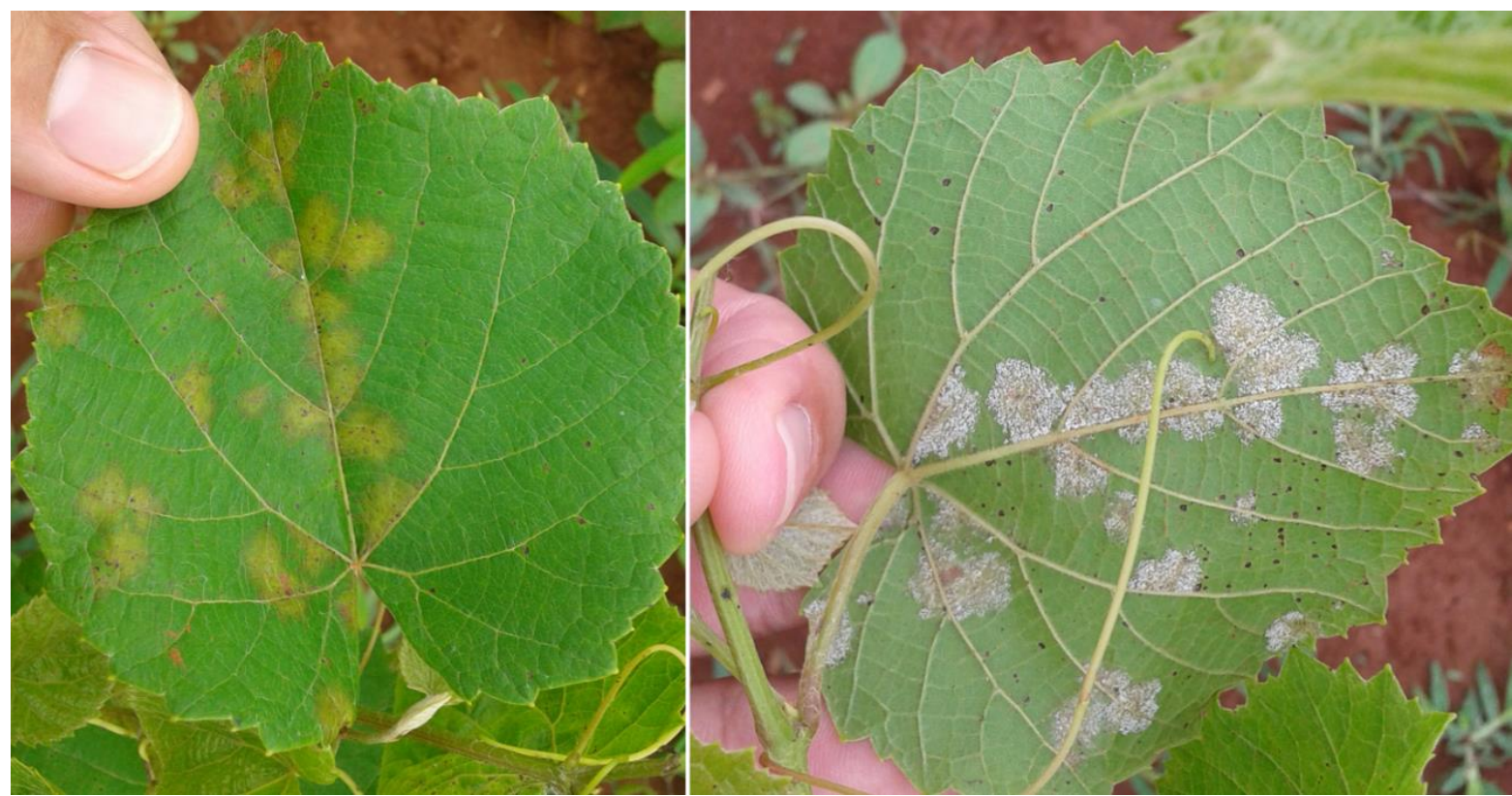
For absolute growth rate in length and diameter of the main branch, there was also an interaction between the factors evaluated (Table 1 and Table 2). For the IAC 572 'Jales' rootstock, the highest absolute growth rate in length $\left(A G R_{c}\right)$ was observed in the period of 45-60 days after pruning, with the highest value being $4.42 \mathrm{~cm}$ $\mathrm{day}^{-1}$. For the IAC 766 'Campinas' rootstock there was no significant difference for the evaluation periods. However, this cultivar showed lower
$A G R_{C}$ value together with IAC 313 'Tropical' in the 90-105 days after pruning. For the rootstock IAC 313 'Tropical', lower values of $A G R_{C}$ were found, with the best performances observed in the range of $45-60$ and $105-120$, with $A_{G R}$ of 3.68 and $0.38 \mathrm{~cm} \mathrm{day}^{-1}$, respectively. Despite this, there was no significant difference isolated, compared to the other rootstocks (Table 1).

Table 1. Interaction for absolute growth rate in length $\left(\mathrm{cm} \mathrm{day}^{-1}\right)\left(A G R_{c}\right)$ of the main branch, in three vine rootstock cultivars (IAC 313 'Tropical', IAC 572 'Jales' and IAC 766 'Campinas') and evaluation intervals.

\begin{tabular}{lccc}
\hline \multirow{2}{*}{ Interval (days) } & \multicolumn{3}{c}{ Rootstocks } \\
\cline { 2 - 4 } & IAC 572 & IAC 766 & IAC 313 \\
\hline $45-60$ & $-1.42 \mathrm{aA}$ & $2.00 \mathrm{aA}$ & $3.68 \mathrm{aA}$ \\
$60-75$ & $2.87 \mathrm{abA}$ & $1.84 \mathrm{aAB}$ & $-0.04 \mathrm{bB}$ \\
$75-90$ & $-0.12 \mathrm{bA}$ & $1.12 \mathrm{aA}$ & $-0.28 \mathrm{bA}$ \\
$90-105$ & $2.69 \mathrm{abA}$ & $-0.10 \mathrm{aB}$ & $-0.02 \mathrm{bAB}$ \\
$105-120$ & $0.47 \mathrm{bA}$ & $2.23 \mathrm{aA}$ & $0.38 \mathrm{abA}$ \\
$120-135$ & $2.32 \mathrm{abA}$ & $0.48 \mathrm{aA}$ & $0.20 \mathrm{bA}$ \\
\hline LSD lines (rootstocks) & \multicolumn{4}{|c}{$\mathbf{2 . 7 7}$} \\
\hline LSD columns (interval) & \multicolumn{3}{c}{3.40} \\
\hline Means followed by a different letter, lower case in the column and upper case in the row, differ by Tukey's test at 5\% \\
probability.
\end{tabular}

For the absolute growth rate in diameter $\left(A G R_{D}\right)$, similar values were found among the rootstocks, except in the interval of 120-135 days after pruning, where the IAC 572 'Jales' rootstock was superior to the others (Table 2). Regarding the evaluation intervals, no significant difference was found for IAC 572 'Jales'. For the IAC 766 'Campinas', the highest $A G R_{D}$ was found in the interval of 75-90 days after pruning, but with values significantly similar to the other intervals, except for $120-135$ days after pruning, when the highest value was found below $A G R_{D}$. For the IAC 313 'Tropical' rootstock, the $A G R_{D}$ was positive only in the intervals of 60 75 and $75-90$ days after pruning.

The superiority in vigor, observed for the cultivar IAC 572 'Jales', was reported by
Pommer (2001), who attributed such vigor to adaptability to the most different types of soils, from those with sandy to clayey texture. According to Hernandes and Martins (2010), it is a rootstock used in different regions, showing great vigor, and it is adapted to different environmental conditions, such as in the Southeast and Northeast, and to acidic soils with the presence of nematodes. It was also found, corroborating the results of this work, the resistance of the leaves of this cultivar to the main diseases belonging to the culture of the vine and thus, consequently, less loss of leaves of the plants.

Table 2. Interaction for absolute growth rate in diameter $\left(m m\right.$ day $\left.^{-1}\right)\left(A G R_{D}\right)$ at grafting height, in three vine rootstock cultivars (IAC 313 'Tropical', IAC 572 'Jales' and IAC 766' Campinas') and evaluation intervals. 


\begin{tabular}{lccc}
\hline \multirow{2}{*}{ Interval (days) } & \multicolumn{3}{c}{ Rootstocks } \\
\cline { 2 - 4 } & IAC 572 & IAC 766 & IAC 313 \\
\hline $45-60$ & $0.01 \mathrm{aA}$ & $0.02 \mathrm{abA}$ & $-0.060 \mathrm{bA}$ \\
$60-75$ & $0.03 \mathrm{aA}$ & $-0.02 \mathrm{abA}$ & $0.020 \mathrm{abA}$ \\
$75-90$ & $0.02 \mathrm{aA}$ & $0.06 \mathrm{aA}$ & $0.060 \mathrm{aA}$ \\
$90-105$ & $0.03 \mathrm{aA}$ & $-0.03 \mathrm{abA}$ & $-0.020 \mathrm{abA}$ \\
$105-120$ & $0.02 \mathrm{aA}$ & $0.02 \mathrm{abA}$ & $-0.004 \mathrm{abA}$ \\
$120-135$ & $0.01 \mathrm{aA}$ & $-0.05 \mathrm{bB}$ & $-0.001 \mathrm{abB}$ \\
\hline LSD lines (rootstocks) & \multicolumn{4}{|}{0.085} \\
\hline LSD columns (interval) & \multicolumn{4}{c}{0.104} \\
\hline Means followed by a different letter, lower case in the column and upper case in the row, differ by Tukey's test at 5\% \\
probability.
\end{tabular}

According to Maia and Camargo (2012), the three cultivars adapt well to tropical conditions in Brazil, but differ in vigor. The most vigorous are the cultivars IAC 572 'Jales' and IAC 313 'Tropical'. The IAC 766 'Campinas', although it has a slower initial development, induces good vigor to the crowns. In this work, despite the IAC 766 'Campinas' showing less development, it differed little from IAC 572 'Jales'. IAC 313 'Tropical' didn't show the ideal and characteristic vigor of the cultivar.

The vegetative development of rootstocks, prior to the grafting operation, is very important because it is related to the synthesis of photoassimilates, which will be used after the field grafting operation. Higher concentrations of carbohydrates in the root system may assist in the vegetative development of the graft, shortening the time required for the formation of the vine and, also, providing the formation of vigorous guides branches (SILVA et al., 2010).

\section{Conclusion}

The IAC 572 'Jales' rootstock cultivar has greater vigor for branch growth, in length and diameter.

The IAC 766 'Campinas' rootstock cultivar, although it has low vigor in branch growth, presents satisfactory development.

Longer-term studies are needed to better understand the behavior of rootstocks.
ALMANÇA, A. M.; LERIN, S.; CAVALCANTI, F. R. Doenças da videira. Informe agropecuário, Belo Horizonte, v. 36, n. 289, p. 70-80, 2015.

ALVARES, C. A.; STAPE, J. L.; SENTELHAS, P. C.; GONÇALVES, J. L. M.; SPAROVEK, G. Köppen's climate classification map for Brazil. Meteorologische Zeitschrift, Stuttgart, v. 22, n. 6, p. 711-728, 2013. https://doi.org/10.1127/09412948/2013/0507

CAMPOS, L. F. C.; ALVES JR., J.; CAMPOS, C. M. A.; CASAROLI, D.; EVANGELISTA, A. W. P.; SELEGUINI, A. Sistema radicular do porta-enxerto IAC 572 'jales' sob Niágara Rosada nas condições do cerrado goiano. Irriga, Botucatu, v. 22, n. 4, p. 723-734, 2017.

https://doi.org/10.15809/irriga.2017v22n4p723$\underline{734}$

CARDOSO, M. R. D.; MARCUZZO, F. F. N.; BARROS, J. R. Classificação climática de KöppenGeiger para o estado de Goiás e o Distrito Federal. ACTA Geográfica, Boa Vista, v. 8, n. 16, p. 40-55, 2014.

http://dx.doi.org/10.5654/acta.v8i16.1384

FERREIRA, D. F. Sisvar: a computer analysis system to fixed effects split plot type designs. Revista brasileira de biometria, Lavras, v. 37, n. 4, p. 529-535, 2019.

https://doi.org/10.28951/rbb.v37i4.450

HERNANDES, J. L.; MARTINS, F. P. Importância do uso de porta-enxertos na viticultura. In: Bueno, $\mathrm{S}$. C. S. (Org.). Vinhedo Paulista. Campinas:

\section{References}


Coordenadoria de Assintência Técnica Integral CATI, 2010. p. 125-129.

LEÃO, P. C. S.; BRANDÃO, E. O.; GONÇALVES, N. P. $S$. Produção e qualidade de uvas de mesa 'Sugraone' sobre diferentes porta-enxertos no Submédio do Vale do São Francisco. Ciência Rural, Santa Maria, v. 41, n. 9, p.1526-1531, 2011. https://doi.org/10.1590/S0103$\underline{84782011000900006}$

LEÃO, P. C. S.; SOARES, J. M. Implantação do vinhedo. In: SOARES, J. M.; LEÃO, P. C. S. (Ed.). A viticultura no semiárido brasileiro. Brasília: Embrapa Informação Tecnológica, Petrolina: Embrapa Semiárido, 2009. p. 257-291.

MAIA, J. D. G.; CAMARGO, U. A. Implantação do vinhedo. In: MAIA, J. D. G.; CAMARGO, U. A. (Eds). O cultivo da videira Niágara no Brasil. Brasília: Embrapa, 2012. p. 33-79.

NAVES, R. L.; GARRIDO, L. R.; SÔNEGO, O. R.; MÁRIO FOCHESATO, M. Antracnose da videira: sintomatologia, epidemiologia e controle. Bento Gonçalves: Embrapa Uva e Vinho, 2006. 32 p. (Circular Técnica, 69).

POMMER, C. V. Cultivares de uva produzidos ou introduzidos pelo IAC. In: BOLIANE, A. C.; CORRÊA, L. S. (Eds.). Cultura de uvas de mesa: do plantio à comercialização. Ilha Solteria: UNESP; FAESP, 2001. 328 p.

SANTOS, H. G.; JACOMINE, P. K. T.; ANJOS, L. H. C.; OLIVEIRA, V. Á.; LUMBRERAS, J. F.; COELHO, M. R.; ALMEIDA, J. A.; CUNHA, T. J. F.; OLIVEIRA, J. B. Sistema brasileiro de classificação de solos. 3.ed. Brasília: Embrapa, 2013. 353 p.

SILVA, L. C.; MACÊDO, N. E.; AMORIM NETO, M. S. Análise do crescimento de comunidades vegetais. Campina Grande: Embrapa Algodão, 2000. 18 p. (Circular Técnica, 34)

SILVA, M. J. R.; TECCHIO, M. A.; MOURA, M. F.; BRUNELLI, L. T.; IMAIZUMI, V. M.; VENTURINI FILHO, W. G. Composição físico-química do mosto e do vinho branco de cultivares de videiras em resposta a porta-enxertos. Pesquisa Agropecuária Brasileira, Brasília, v. 50, n. 11, p. 1105-1113, 2015. https://doi.org/10.1590/S0100$\underline{204 \times 2015001100014}$
SILVA, M. J. R.; VEDOATO, B. T. F.; LIMA, G. P. P.; MOURA, M. F.; COSER, G. M. A. G.; WATANABE, C. Y.; TECCHIO, M. A. Phenolic compounds and antioxidant activity of red and white grapes on different rootstocks. African Journal of Biotechnology, v. 16, n. 13, p. 664-671, 2017. https://doi.org/10.5897/AJB2016.15837

SILVA, T. P.; PIO, R.; SALIBE, A. B.; DALASTRA, I. M.; STANGARLIN, J. R.; KUHN, O. J. Avaliação de porta-enxertos de videira em condições subtropicais. Bragantia, Campinas, v. 69, n. 1, p. 93-97, 2010. https://doi.org/10.1590/S000687052010000100013

SOUSA, D. M. G.; LOBATO, E. Eds. Cerrado: correção do solo e adubação. Planaltina: Embrapa Cerrados, 2004. 416 p.

SOUZA, E. R.; RIBEIRO, V. G.; MENDONÇA, O. R.; SANTOS, A. S.; SANTOS, M. A. C. Comprimentos de estacas e AIB na formação de porta-enxertos de videira 'Harmony' e 'Campinas'. Revista Brasileira de Tecnologia Aplicada nas Ciências Agrárias, Guarapuava, v. 5, n. 2, p. 19-32, 2012. https://doi.org/10.5777/paet.v5i2.1584

SOUZA, J. S. I., MARTINS, F. P. Viticultura brasileira: principais variedades e suas características. Piracicaba: FEALQ, 2002. 368 p.

TECCHIO, M. A, SILVA, M. J. R., SÁNCHEZ, C. A. P. C, WATANABE, C. Y., MOURA, M. F., LEONEL, S., PIMENTEL-JÚNIOR, A. The influences of rootstock and pruning seasons on productive and physicochemical traits of 'Niagara Rosada' grape. Australian Journal of Crop Science, n. 13, v. 7, p. 1211-1214, 2019.

https://doi.org/10.21475/ajcs.19.13.07.p2044

TERRA, M. M.; POMMER, C. V.; PIRES, E. J. P.; RIBEIRO, I. J. A.; GALLO, P. B.; PASSOS, I. R. S. Produtividade de cultivares de uvas para suco sobre diferentes porta-enxertos IAC em MococaSP. Revista Brasileira de Fruticultura, Jaboticabal, v. 23, n. 2, p. 382-386, 2001.

https://doi.org/10.1590/S010029452001000200037 